\title{
THE IMPACT OF ENTERPRISE RESOURCE PLANNING AND AUDIT COMMITTEE ON ACCOUNTING INFORMATION QUALITY
}

\author{
Krismiaji \\ Accounting Department, Accounting Academy YKPN \\ Yogyakarta, Indonesia \\ e-mail: xmiaji@gmail.com \\ Y Anni Aryani \\ Accounting Department, Fakultas Ekonomi dan Bisnis (FEB) \\ Universitas Sebelas Maret (UNS) \\ Surakarta, Indonesia \\ e-mail: y_anniar@yahoo.com
}

\begin{abstract}
This paper discusses the impact of ERP implementation and audit committee on the accounting information quality. This quality is measured with absolute discretionary accrual. The impact of audit committee is measured with audit committee score. In this study, ERP implementation is treated as a dummy variable, which is set as 1 for companies that implement ERP and 0 for companies that do not implement ERP. The population of this study is all of the companies listed in the Indonesia Stock Exchange. The sampling method employed in this study is purposive sampling. By using a sample of 78 publicly listed companies in the Indonesia Stock Exchange for the fiscal year of 2010 to 2011, this study presents evidence of a negative impact of ERP implementation on the accounting information quality. This study also finds that audit committee has a po sitive impact on the accounting information quality produced by companies that implement ERP.
\end{abstract}

Keywords: ERP, Reliability, Audit committee

\begin{abstract}
Abstrak
Artikel ini mendiskusikan dampak implementasi ERP dan komite audit terhadap kualitas informasi akuntansi. Kualitas ini diukur dengan absolute discretionary accrual. Dampak dari komite audit diukur dengan skor komite audit. Dalam studi ini, implementasi ERP dianggap sebagai variabel dummy yang ditetapkan sebagai 1 untuk perusahaan yang mengimplementasikan ERP dan 0 untuk perusahaan yang tidak mengimplementasikan ERP. Populasi studi ini adalah semua perusahaan yang terdaftar di Bursa Efek Indonesia. Metode sampling yang digunakan di studi ini adalah purposive sampling. Dengan menggunakan 78 perusahaan yang terdaftar secara publik di Bursa Efek Indonesia untuk tahun fiskal 2010 hingga 2011, studi ini menampilkan fakta adanya dampak negatif dari implementasi ERP terhadap kualitas informasi akuntansi. Studi ini juga menemukan bahwa komite audit mempunyai dampak positif terhadap kualitas informasi akuntansi di perusahaan-perusahaan yang mengimplementasikan ERP.
\end{abstract}

Kata kunci: ERP, Reliabilitas, Komite audit

\section{INTRODUCTION}

This paper discusses the effect of enterprise resource planning (ERP) implementation and audit committee on the accounting information quality. ERP system is an integrated in- formation system. This system consists of a set of structured and integrated modular software that includes and supports most of business processes (Hitt, Wu and Zhou 2002; Poston and Grabski 2001). Prior literature 
claim that the ERP implementation have many benefits, such as assisting the business process reengineering (O'Leary 2008; Bradford and Robert 2001; Winters 2004), increasing operational performance (Hayes, Hunton and Reck 2001; Hunton, Lippincott and Reck 2003), improving managers ability to process and analyze accounting information (Davenport 1998; Hitt et al. 2002), providing information that enable management to have a whole view of firm's financial condition (Dillon 1999), decreasing function barriers, and enabling managers to access accounting information quickly (O'leary 2008).

However, ERP system implementation also raises new problems. Previous research shows that firms' external audit quality decreases when ERP system is implemented (Hunton, Wright and Wright 2004) and this problem may be caused by financial auditors who do not fully realize the exposure risks of ERP system. Additionally, there is a prior study that finds a decrease in internal control effectiveness after ERP implementation (Wright and Wright 2002). The study by Wright and Wright (2002) also shows that the ERP implementation process has an impact on the system reliability.

Many countries have implemented regulations that require firms to disclose the weaknesses of their internal control system. One of those countries is the United States with its Sarbanes-Oxley Act of 2002 (SOX 2002). Under the SOX 2002, the reliability of financial information should be increased due to the increase of internal control quality and audit quality conducted by the external auditors. Nevertheless, prior literature demonstrate that the audit quality and the internal control system decrease after the implementation of ERP system (Wright and Wright 2002; Hunton et al. 2004). Specifically, Brazel and Dang (2008) find the increase of absolute discretionary accrual after the implementation of ERP system. This implies that after the implementation of ERP system, the reliability of accounting information quality decreases even though it has an environment with powerful internal control rules. The increase of absolute discretionary accrual provides evidence of the increase of earning management.

The debatable benefit of ERP system implementation raises a question whether or not the ERP system implementation decrease the reliability of accounting information due to the decrease of audit quality and the decrease of the effectiveness of internal control, especially in Indonesia. Indonesia does not have a regulation like SOX 2002. However, it has similar regulations with the same purpose. Since 2004, Indonesia has implemented a regulation issued by Capital Market Supervisory Agency No. Kep-29/PM/2004 concerning the establishment and guidance of Audit Committee implementation. The objective of this regulation is to ensure a good quality of accounting information published by companies listed in the Indonesia Stock Exchange.

By implementing such regulation, it is argued that accounting information quality increases after implementing ERP system. Nevertheless, this argument needs to be further investigated in order to get empirical evidence. To our knowledge, there is a little (if any) empirical studies about the impact of ERP implementation and audit committee on accounting information quality, especially in Indonesia. This motivates us to conduct a research about the joint impact of ERP implementation and audit committee on the accounting information quality. Based on the description above, a research question can be formulated as follows: do ERP implementation and audit committee influence accounting information quality resulted by companies listed in the Indonesia Stock Exchange?

The remainder of the paper is structured as follows: section two discusses the literature review along with the hypotheses development. The research method and results discussion are presented in the third and fourth sections, respectively. Finally, the fifth section presents conclusions along with implication of this study, limitations and suggestions for further research. 


\section{LITERATURE REVIEW AND HYPO- THESES DEVELOPMENT}

\section{Enterprise Resource Planning (ERP) im- plementation and Reliability}

One of the advantages of the ERP system implementation is the ability to improve internal management decision-making. This condition should enable the firms that implement ERP system to perform better than non-ERP firms (Hunton et al. 2003). The ERP system implementation also improves the ability of managers to manage financial information for external users. ERP system is able to improve information set of management and to increase the asymmetry information level between managers and external financial report users. Prior research has empirically shown that higher level of asymmetry information and the related agency cost increases the investor's attention toward quality of reported earnings (Chow 1982; Francis and Wilson 1988). Therefore, the higher level of asymmetry information between management and investor increase the moral hazard problem because management can use higher discretion in earning reporting. This happens because the management has more control over the internal information regarding the firm's financial conditions than investors.

The information time lag on legacy system often forces management to manage extenal accounting information by conducting more transparent adjustments at the year-end period. Such adjustment is easier to be identified and questioned by external auditors (Lanza and Gilbert 2007). On the other hand, the constant accounting information flow and the enterprisewide view that is the outcome of ERP system give management the opportunity to manage accounting information continuously at anytime.

Basically, earnings management is not a simple game. It requires multi-period planning because accrual manipulation in one year will affect subsequent years (Brazel and Dang 2008). ERP implementation facilitates multiperiod accrual planning. Therefore, ERP system helps management to conduct earnings management. If ERP implementation allow managers greater access and control over financial accounting data (Dillon 1999), the opportunity for management to interpret financial statement to meet incentives is increased. Therefore, ERP implementation should improve the ability of managers to respond to market and contractual incentives by managing earnings.

Financial statement audits and related internal controls are instruments that can reduce management opportunities to conduct financial statement management. Prior research found a positive relationship between discretionary levels and audit quality (Becker, DeFond, Jiambalvo, and Subramanyam 1998). When the opportunity to manage financial statement decrease, a company is able to produce more reliable financial statement for external users. The objective of the audit is to determine whether, in all material respects, the financial statements are prepared according to the GAAP (AICPA 1972). Hogan and Wilkins (2005) found that audit functions as a constraint in potential earnings management. Previous research also found that reported material weaknesses in internal control are associated with lower earnings quality (Doyle, Ge and McVay 2005; Chan, Farrel, and Lee 2008). Extant research also indicates that safeguards to reliability may be impaired in an ERP system setting. Hunton et al. (2004) and Brazel and Agoglia (2007) reported that auditor risk assessment and testing quality might be inadequate for clients that have implemented an ERP system. Wright and Wright (2002), through semi-structured interviews with IT audit specialists found that 31.8 percent of their participants had experiences in practice where their client's ERP system lacked adequate controls.

Following an ERP system implementation, the opportunity to manage financial accounting information may increase due to enhanced managerial information access and control and reductions in the safeguards of audit quality and internal control effectiveness. Policy makers (AICPA 2002) state that opportunity 
is an important component affecting whether managers actually do manage accounting information to report financial results that meet their objectives, but do not reflect the true financial condition of the firm. Thus, the reliability of accounting information may be damaged by implementation of ERP system. We therefore test the following hypothesis:

$\mathrm{H}_{1}$ : ERP system implementation decreases the reliability of accounting information.

\section{Audit Committee and Reliability}

Previous research investigated the effect of corporate governance on reliability of accounting information was conducted by Habbash (2010), who reported that the size and Board of Commisioner (BOC) independence, competence and independence of audit committee, independence of nomination committee, independence of head of BOC, amount of non-executive directors' remuneration, and independence and external auditor specialization negatively associated with earnings management significantly. Furthermore, other research conducted by Roodposhti and Chashmi (2010), Verriest and Gaeremynck (2008), Baxter and Cotter (2006), Bugshan (2005), and Li (2009) that employed earnings management proxy also found similar results.

Previous research that used magnitude of abnormal accrual (discretionary accrual) and accrual quality found that the strong corporate governance negatively associated with abnormal accrual (discretionary accrual) or the strong corporate governance increased earnings reliability. These findings had been docummented by Lara, Osma, and Penalva (2007), Kiatapiwat (2010), Moradi and Nezami (2011), Nasr, Boubakri, dan Cosset (2009), Shivaramakrishnan and $\mathrm{Yu}$ (2008), Dhaliwal, Naiker, and Navissi (2007), Houqe, Zijl, Dunstan, and Karim (2010), Kent, Routledge, and Steward (2008), Mitra (2002), Hashim and Devi (2008).

Garven (2009) found that audit committee and characteristics of BOC negatively associated with REM, whereas Ismail, Dunstan, and Zijl (2010) found that BOC and size of audit committee positively associated with earnings quality (reliability). Klein (2006) found that a non-linear negative relation is found between audit committee independence and earnings manipulation. Other research conducted by Beasley and Salterio (2001), McMullen and Raghunandan (1996), DeZoort and Salterio (2001) support the finding that the existence of audit committee increase financial reporting quality, whereas Dechow, Sloan, and Sweeney (1996) find that companies without audit committee are more likely to be involved in a financial fraud. Based on the previous research regarding the effect of audit committee on accounting information reliability or reliability, we state hypothesis as follows:

$\mathrm{H}_{2}$ : Audit committee positively affects reliability of accounting information

\section{RESEARCH METHODOLOGY}

\section{Sample Selection}

The population of this study is all companies listed in the Indonesia Stock Exchange. The sampling method employed in this study is purposive sampling. The samples in this study are companies that fulfill criteria such as having complete financial and audit committee data. Data sources used in this study are the Indonesia Capital Market database and companies website.

\section{Research Design}

Reliability quality is measured with one of variables used by Barua (2006), which is abnormal accrual. Abnormal accrual is estimated with Modified-Jones Model developed by Dechow et al. (1996) in equation (1).

$$
\begin{aligned}
T A_{i t}= & \beta_{1}\left(1 / A_{\mathrm{it}-1}\right)+\beta_{2}\left(\Delta R E V_{\mathrm{it}}-\Delta R E C_{\mathrm{it}}\right)+\beta_{3} \\
& P P E_{\mathrm{it}}+\varepsilon_{i t} \ldots \ldots \ldots \ldots \ldots \ldots \ldots \ldots \ldots \ldots \ldots \ldots \ldots \ldots \ldots \ldots \ldots \ldots \ldots \ldots \ldots \ldots \ldots \ldots \ldots \ldots \ldots \ldots
\end{aligned}
$$

Where:

$$
\begin{aligned}
\mathrm{TA}_{\mathrm{it}}= & \text { total accrual scaled by total asset } \\
& \text { for firm sample } \mathrm{i} \text { at period } \mathrm{t}, \\
\mathrm{A}_{\mathrm{it}-1}= & \text { lagged total asset, for firm sample } \\
& \mathrm{i} \text { at period } \mathrm{t}-1,
\end{aligned}
$$


$\Delta \mathrm{REV}_{\mathrm{it}}=$ changes on net income for firm sample $\mathrm{i}$ at period $\mathrm{t}$,

$\Delta \mathrm{REC}_{\mathrm{it}}=$ changes on net receivable for firm sample $\mathrm{i}$ at period $\mathrm{t}$,

$\mathrm{PPE}_{\mathrm{it}}=$ gross fixed asset for firm sample $\mathrm{i}$ at period $t$, and

$\varepsilon_{\mathrm{it}} \quad=$ error term.

Discretionary accrual for the year is residual value of equation (1). Absolute discretionary accruals (ABSDA) is a proxy of reliability. The greater magnitude of ABSDA, the lower is the quality of reliability.

Audit committe is an independent variable and measured with audit committe score, based on decision of Capital Market Supervisory Agency (Kep-29/PM/2004) and several previous research done by Ramral (2011) and Ananchotikul (2007). Meanwhile, ERP is a dummy and independent variable. This variable is stated to 1 for a company which implements ERP system and 0 for a company which does not implement ERP system. Control variables used in this research are: Firm-size (Size) which is calculated with natural log of total assets, Market-to-book ratio (MTB) which is calculated by dividing market value of firm equity with book value of firm equity. Previous research done by Zhou and Elder (2001) found that firm's market-to-book-value (MTB) is a proxy for growth opportunities and may influence discretionary accruals. Leverage is another control variable and it is calculated by dividing total liabilities with total assets. Previous research concludes that leverage (Lev) correlated with discretionary accruals (DeFond and Jiambalvo, 1994; Becker et al. 1998).

\section{Model Specification}

The main statistical method to test hypotheses is GLS regression. The GLS models to be estimated are as follow:

$$
\begin{aligned}
\mathrm{ABSDA}= & \beta_{0}+\beta_{1} \mathrm{ERP}+\beta_{2} \mathrm{AC}+\beta_{3} \mathrm{SIZE}+ \\
& \beta_{4} L E V+\beta_{5} M T A \quad \varepsilon \ldots \ldots \ldots \ldots \ldots .(2)
\end{aligned}
$$

Where:

ABSDA $=$ absolute discretionary accrual and the proxy of reliability quality,
$\mathrm{ERP}=$ dummy variable which is stated to 1 for a company which implement ERP system and 0 for a company which does not implement ERP system.

$\mathrm{AC}=$ audit committee,

Size $=\log$ of total assets,

Lev = total liabilities divided by total assets,

MTB $=$ market to book value equity, and

$\varepsilon \quad=$ error term.

\section{RESULTS AND DISCUSSION}

Based on the sampling process described above, this study used 78 firms as samples to be included in this research. The samples consist of 39 ERP-adopted and 39 non-ERPadopted firms for two years. The total observation conducted is 156 firm-years. Moreover, in order to be comparable, both the ERP-adopted firms and non-ERP-adopted firms selected in this study cme from a similar sector. The data sample is presented in Table 1 below.

Table 2 shows descriptive statistics for the data sample. From Table 2, it can be seen that the mean of ABSDA is 0,068 with standard deviation of 0,060 . The range between maximum $(0,284)$ and minimum value $(0,001)$ is 0,283 . Since this variable is an inverse measure of predictive value quality, hence, the smaller the value, the better is the quality.

ERP has a mean value of 0,500 with standard deviation of 0,501 . The range between maximum $(1,000)$ and minimum value $(0,000)$ is 1,000 . AC score has mean value of 0,813 with standard deviation of 0,087 . The maximum value of $\mathrm{AC}$ is 1,000 and minimum value of 0,590 , so this variable has range of 0,410 . The mean of MTB is 2,331 with standard deviation of 3,950. The maximum value of MTB is 38,970 and minimum value of 0,091 , so this variable has a range of 38,869 . Lev has a mean value of 0,483 with standard deviation of 0,198 . The range between maximum $(1,070)$ and minimum value $(0,070)$ is 1,000 . The mean of Size is 13,414 with standard deviation of 3,317 . The maximum value of Size is 18,849 and minimum value of 4,768 , so this variable has range of 14,081 . 
Table 1: Firms Data Sample

\begin{tabular}{lc}
\hline Firms listed in Indonesia Stock Exchange in 2010 and 2011 & 459 \\
\hline Deducted: & 298 \\
- Firms with incomplete data & 83 \\
- Firms in financial industry & $\mathbf{7 8}$ \\
Final Samples & \\
\hline
\end{tabular}

Table 2: Descriptive Statistics

\begin{tabular}{cccccc}
\hline & Mean & Median & Maximum & Minimum & Std. Dev. \\
\hline ABSDA & 0,068 & 0,051 & 0,284 & 0,001 & 0,060 \\
ERP & 0,500 & 0,500 & 1,000 & 0,000 & 0,501 \\
AC & 0,813 & 0,800 & 1,000 & 0,590 & 0,087 \\
MTB & 2,331 & 1,355 & 38,970 & 0,091 & 3,950 \\
Lev & 0,483 & 0,510 & 1,070 & 0,070 & 0,198 \\
Size & 13,414 & 14,042 & 18,849 & 4,768 & 3,317 \\
\hline
\end{tabular}

\section{Hypothesis Testing}

In order to test the hypotheses, this study used regression statistics analysis with software EVIEWS. The classic assumptions of regression model were tested before the regression statistics analysis was conducted. The assessment shows that the data were normally distributed and there were no problems with multicolinearity, heteroscedasticity, and autocorrelation in the data. The regression analysis results and reliability quality testing is presented in Table 3.

Regression results show that determination coefficient $\left(A d j . R^{2}\right)$ is 0,098 or 9,8 percent. This number shows that all independent variables are only able to explain 9,8 percent effect of independent variables on dependent variable, and the rest are explained by other variables which are not taken into account in this research.

Table 3 shows a significant $(\mathrm{p}=0.031)$ and positive coefficient for ERP. Since ABSDA is an inverse measure of reliability quality, this result indicates that reliability decrease in the firms that implement ERP systems. Therefore, this result supports $\mathrm{H} 1$ of this research. This result also provides evidence that after ERP implementation, the discretionary accrual number increase. The finding of this study is consistent with prior research by Brazel and Dang (2008), Brazel and Agoglia (2007); and Hunton et al. (2003) who find that ERP implementation reduces reliability quality of accounting information.

Table 3:Regression Analysis

\begin{tabular}{lccc}
\hline \multicolumn{2}{c}{$\mathbf{A B S D A}=\boldsymbol{\beta}_{\boldsymbol{0}}+\boldsymbol{\beta}_{\boldsymbol{1}} \mathbf{E R P}+\boldsymbol{\beta}_{\mathbf{2}} \mathbf{A C}+\boldsymbol{\beta}_{\mathbf{3}} \boldsymbol{S I Z E}+\boldsymbol{\beta}_{\mathbf{4}} \boldsymbol{L E} \boldsymbol{V}+\boldsymbol{\beta}_{\mathbf{5}} \boldsymbol{M T \boldsymbol { B }}+\boldsymbol{\varepsilon}$} \\
\hline \multicolumn{1}{c}{ Variable } & Coefficient & Std. Error & P-value. \\
\hline (Intercept) & $0.136^{* * *}$ & 0.040 & 0.000 \\
ERP & $0.033^{* *}$ & 0.015 & 0.031 \\
AC & $-0.228^{* * *}$ & 0.043 & 0.000 \\
LEV & $0.017^{*}$ & 0.010 & 0.071 \\
MTB & 0.000 & 0.000 & 0.571 \\
SIZE & 0.000 & 0.000 & 0.756 \\
Adjusted R-squared & 0.098 & & \\
F-statistic & $2.532^{* * *}$ & & 0.005 \\
\hline
\end{tabular}


For hypothesis 2 , the result shows that the value of $\beta_{2}$ equals to $-0,228$ and significant in the level $\alpha=0,01$. It means that AC positively and significantly affects reliability. Therefore, there is empirical evidence to accept $\mathrm{H}_{2}$. It can be concluded that $\mathrm{H}_{2}$ that states that audit committee have positive effect on reliability of accounting information is supported by empirical data of this study. This result is consistent with studies conducted by Beasely and Salterio (2001), DeZoort and Salterio (2001), and McMullen dan Raghunandan (1996) who found that the existence of audit committee increases the quality of financial reporting. This result is also in line with previous research by Garven (2009) who found that audit committee associated with REM; Ismail, Dunstan, and Zijl (2010) who found that size of audit committee positively associated with earnings quality (reliability); and Klein (2006) who discovered that a non-linear negative relation is found between audit committee independence and earnings manipulation.

\section{CONCLUSION}

This research provides evidence that ERP implementation has negatively affect the reliability quality of accounting information produced by companies listed in the Indonesian Stock Exchange. These results show that the reliability of accounting information quality decrease for companies which implement ERP. These results support $\mathrm{H}_{1}$ which states that ERP implementation negatively affect the reliability of accounting information quality. Therefore, it can be concluded that as a whole, ERP implementation negatively affects accounting information quality.

The data analysis conducted in this study also demonstrates that audit committee significantly and positively affect the reliability of accounting information produced by companies listed in the Indonesia Stock Exchange. This result demonstrates that the reliability of accounting information increase post-ERP implementation. This result supports $\mathrm{H}_{2}$ of this study which states that audit com- mittee positively affect the reliability of accounting information. Therefore, it can be concluded that as a whole, audit committee positively affects accounting information quality.

This research has several implications. Firstly, the results confirm the agency theory, which predicts that monitoring and controlling activities by independent parties such as audit committee ensure the agent acts on behalf of the principle interest, so the accounting information quality increase. Secondly, the results give an understanding that the expected benefit from ERP implementation, which is an increase of the accounting information quality, cannot be achieved. This should become one of the main concerns for the companies' management. As previously mentioned, there are several factors that contribute to the decrease of the reliability of accounting information quality such as the quality of auditors who do not have sufficient familiarity with ERP.

This research has several limitations. Firstly, this study uses a small sample size. This limitation should be considered when making any conclusions and generalization of the results. Secondly, this study compares between companies that implement ERP and companies that do not implement ERP. The different characteristic between the two sample groups may limit the generalization of the results of this study. Thirdly, this study does not take into account the industry characteristic. Fourthly, this research does not use market data to measure the accounting information quality. However, these limitations offer avenues for further research in this area. Firstly, similar research can be done by using another accounting quality measurement that is more market-oriented such as earnings response coefficient (ERC). Secondly, further research can employ pre- and post-design, which aims to compare between period before and after ERP implementation. Thirdly, research can also be conducted by considering industry characteristics in order to distinguish one industry from another. 


\section{REFERENCES}

American Institute of Certified Public Accountants (AICPA). 1972. Statement on Auditing Standards No. 1: Codification of Auditing Standards and Procedures. New York, NY: AICPA.

. 2002. Statement on Auditing Standards No. 99: Consideration of Fraud in a Financial Statement Audit. New York, NY: AICPA.

Ananchotikul, N. 2007. Does foreign direct investment really improve corporate governance? Evidence from Thailand. Working paper. University of California, Berkeley

Barua, A. 2006. Using the FASB qualitative characteristics in earnings quality measures. Dissertation. Louisiana State University.

Baxter, P., and J. Cotter. 2006. Audit committees and earnings quality. Working paper. University of Southern Queensland, Australia.

Beasley, M. S., and Salterio, S. E. 2001. Relation between board characteristics and voluntary improvements in audit committee composition and experience. Contemporary Accounting Research 18 (4): 539-570.

Becker, C.I., M.L. DeFond., J. Jiambalvo., and K.R. Subramanyam. 1998. The effects of audit quality on earnings management. Contemporary Accounting Research 15 (1): 1-21.

Bradford, M., and F. D. Roberts. 2001. Measuring value in ERP installations. Strategic Finance, (September): 30-34.

Brazel, J. F., and C. P. Agoglia. 2007. An examination of auditor planning judgments in a complex AIS environment. Contemporary Accounting Research 24 (4): 1059-1083.

Brazel, J. F., and Li Dang. 2008. The Effect of ERP System Implementations on the
Management of Earnings and Earnings Management. Journal of Information Systems; Fall 2008; 22, 2: 1-21.

Bugshan, T. 2005. Corporate governance, earnings management, and the information content of accounting earnings: Theoretical model and empirical tests. Dissertation. Bond University Queensland 4229 Austalia.

Chan, K.C., B.R. Farrel, and P. Lee. 2008. Earnings management of firm reporting internal control weaknesses under section 404 of the Sarbanes-Oxley Act. Auditing: Journal of Practice \& Theory 27 (2): 161 -179.

Chow, C. 1982. The demand for external auditing: Size, debt, and ownership influences. The Accounting Review 57 (2): 272-291.

Davenport, T. 2000. Mission critical: Recognizing the promise of enterprise systems. Cambridge, MA: Harvard University Press.

Dechow, P., R. Sloan., and A. Sweeney. 1996. Causes and consequences of earnings manipulation: An analysis of firms subject to enforcement actions by the SEC, Contemporary Accounting Research 13 (1): 1-36.

DeFond M.L., and J. Jiambalvo. 1994. Debt covenant violation and manipulation of accruals. Journal of Accounting and Economics 17 (1-2): 145-176.

DeZoort, F. and S. Salterio. 2001. The effects of corporate governance experience and financial reporting and audit knowledge on audit committee members' judgments", Auditing: A Journal of Practice \& Theory 20 (2): 31-47.

Dhaliwal, D., V. Naiker, and F. Navissi. 2007. Audit committee financial expertise, corporate governance and accruals quality: An empirical analysis. Working Paper. 
Dillon, C. 1999. Stretching towards enterprise flexibility with ERP. APICS-The Performance Advantage (October): 38-43.

Doyle, J. T., W. Ge, and S. E. McVay. 2005. Determinants of weaknesses in internal control over financial reporting and the implications for earnings quality. Working Paper, University of Utah.

Francis, J., and E. Wilson. 1988. Auditor changes: A joint test of theories related to agency costs and auditor differentiation. The Accounting Review 63 (4): 663-682.

Garven, S. A. 2009. The effect of board and audit committee characteristics on real earnings management: Do boards and audit committees play a role in its constraint?. Working paper. The University of Alabama.

Habbash, M. 2010. The effectiveness of corporate governance and external audit on constraining earnings management practice in UK. Dissertation. Durham University.

Hashim, H. A., and S.S. Devi. 2008. Corprate governance, ownership structure and earnings quality: Malaysian evidence. Working paper. Universiti Malaya, Malaysia.

Hayes, D. C., J. E. Hunton., and J. L. Reck. 2001. Market reaction to ERP implementation announcements. Journal of Information Systems 15 (1): 3-18.

Hitt, L. M., D. J. Wu, and X. Zhou. 2002. Investment in enterprise resource planning: Business impact and productivity measures. Journal of Management Information Systems 10 (1): 71-98.

Hogan, C., and Wilkins, M., 2005. Internal control weaknesses and earnings management. Working paper, Southern Methodist University and Texas A\&M University
Hribar, P., and D.W. Colins. 2002. "Errors in estimating accruals: implications for empirical research", Journal of Accounting Research 40 (1): 105-134.

Houqe, M. N., K. Dunstan, W. Karim, and T. V. Zijl. 2010. The effect of IFRS Adoption and Investor Protection on Earnings Quality around the World. Working Paper. Victoria University of Wellingon .

Hunton, J. E., B. Lippincott., and J. L. Reck. 2003. Enterprise resource planning systems: Comparing firm performance of adopters and nonadopters. International Journal of Accounting Information Systems 4 (3): 165-184.

Hunton, J. E. 2004. Are financial auditors overconfident in their ability to assess risks associated with enterprise resource planning systems? Journal of Information Systems 18 (2): 7-28.

International Accounting Standard Board (IASB). 2008. Exposure Draft of An Improval Conceptual Framework for Financial Reporting. Chapter 2: Qualitative Characteristics and Constraints of Decision Useful Financial Reporting Informations.

Ismail, W. A., .W., K. Dunstan, and T. V. Zijl. 2010. Earnings quality and corporate governance following the implementation of malaysian code of corporate governance. Working paper. Victoria University of Wellington.

Kent, P., J. Routledge., and J. Stewart. 2008. Innate and discretionary accrual quality and corporate governance. Working paper. Bond University. Gold Coast. Available at http://epublications.bond.edu.au/busine ss_pubs/110

Kiatapiwat,W. 2010. Controlling shareholders, audit committee effectiveness, and earnings quality: the case of Thailand. 
Dissertation. University of Maryland, College Park.

Klein, A. 2006. Audit committee, board of director characteristics, and earnings management. Law \& economics research paper series, working paper no. 06-42, New York University School Of Law. http://ssrn.com/abstract=246674

Lanza, R. B., and S. Gilbert. 2007. A riskbased approach to journal entry testing: How software can help auditors detect fraud. Journal of Accountancy 204 (1): 32-35.

Lara, J. M. G., B. G. Osma., and F. Penalva. 2007. Accounting conservatism and corporate governance. Review Accounting Studies 14 (1): 161-201.

Li, T. 2009. Earnings Quality and Corporate Governance. Master Thesis Accountancy. Tillburg University.

McMullen, D. A., and K. Raghunandan. 1996. Enhancing audit committee effectiveness. Journal of Accounting. 182 (2): 79

Mitra, S. 2002. The impact of institutional stock ownership on a firm's earnings management practice: An empirical investigation. Dissertation. Louisiana State University.

Moradi M. A., and A. Nezami. 2011. Influence of ownership structure on earning quality in the listed firms of Tehran Stock Exchange. International Journal of Business Administration 2 (4): 146 154.

Nasr, B. H., N. Boubakri., and J-C. Cosset. 2009. Ownership structure and earnings quality: Evidence from newly privatized firms. Working Paper.

O'Leary D. E. 2008. Enterprise Resource Planning Systems: Systems, Life Cycle,
Electronic Commerce, and Risk. Cambridge, UK: Cambridge University Press.

Poston, R., and S. Grabski. 2001. Financial impacts of enterprise resource planning implementations. International Journal of Accounting Information Systems 2 (4): 271-294.

Ramral, V. L. 2011. A framework for the Construction of a Corporate Governance Index for Trinidad \& Tobago. Working Paper. Salises. UWI. St. Augustine.

Roodposhti, F. R., and S. A. N. Chashmi. 2010. The effect of board composition and ownership concentration on earnings management: Evidence from Iran. World Academy of Science, Engineering and Technology 4 (6): 673-679.

Sivaramakrishnan K., and S.C. Yu. 2008. On the association between corporate governance and earnings quality. Working paper. University of Houston

Verriest, A., and A. Gaeremynck. 2008. The impact of governance on IFRS restatement quality. Working paper. Katholieke Universiteit, Leuven.

Winters, B. I., 2004. Choose the right tools for internal control reporting. Journal of Accountancy 197 (February): 34-40.

Wright, S., and A. Wright. 2002. Information system assurance for enterprise resource planning systems: Implementation and unique risk considerations. Journal of Information Systems 16: 99113.

Zhou, J., and R. Elder. 2001. Audit Firm Size, Industry Specialization and Earnings Management by Initial Public Offering Firms. Working Paper, SUNY at Binghamton. 